\title{
New Thyroptera tricolor Spix records in the Atlantic Forest, Brazil (Chiroptera; Thyropteridae)
}

\author{
Esbérard, CEL. ${ }^{\mathrm{a} *}$, Santos, BS. ${ }^{\mathrm{b}}$ and Faria, $D .^{\mathrm{b}}$ \\ aDepartamento de Biologia Animal, Instituto de Biologia, Universidade Federal Rural do Rio de Janeiro - UFRRJ, \\ CP 74507, CEP 23890-000, Seropédica, RJ, Brazil \\ bepartamento de Ciências Biológicas, Universidade Estadual de Santa Cruz, \\ Rodovia Ilhéus-Itabuna, Km 16, CEP 45650-000, Ilhéus, Bahia, Brazil \\ *e-mail: cesberard@ superig.com.br
}

Received July 12, 2005 - Accepted December 2, 2005 - Distributed May 31, 2007

(With 1 figure)

Spix's disc-winged bat is a poorly known species that inhabits lowland Neotropical forests (Wilson and Findley, 1977). This bat roosts in young, rolled-up Heliconia or Calathea leaves, forming "behaviourally cohesive social groups of mixed sex" (Vonhof et al., 2004) that range in size from one to 14 individuals (Findley and Wilson, 1974; Wilson and Findley, 1977; Vonhof et al., 2004). Density estimates for this species reached 43 bats / ha- ${ }^{-1}$ in an area of 5.69 ha in Costa Rica (Vonhof and Fenton, 2004). Thyroptera tricolor occurs from Mexico to southeastern Brazil, being found in the Amazonian and Atlantic Forest biomes (Wilson and Findley, 1977). Except for two individuals, captured in Iguape, São Paulo State, southeastern Brazil and identified initially by Vieira (1942) as Thyroptera albiventer juquiaensis and later as T. tricolor juquiaensis (Vizotto and Taddei, 1973) and the second in Angra dos Reis, Rio de Janeiro (Vieira, 1955), nothing further has been published concerning this species in the Atlantic Forest. Thyroptera tricolor juquiaensis can be distinguished from $T$. $t$. tricolor by the yellow abdominal fur and the smaller-sized forearms (Gregorin et al., 2006). Until now, the recorded occurrence of this subspecies has been restricted to southern Brazil (Vieira, 1955).

Five new Atlantic Forest records are currently available that date from at least 50 years after the capture of the vouchers of the subspecies (Vieira, 1942).

Records from Rio de Janeiro, southeastern Brazil - One adult male with descended testes (forearm length of $36.95 \mathrm{~mm}$ and weight of $7 \mathrm{~g}, 01 / 02 / 1997$ ) was netted at 4 hours and 50 minutes, over a small stream in the Rio das Pedras Reserve, Mangaratiba, RJ (22 $52^{\circ}$ ' 18,6” S and $44^{\circ} 06^{\prime} 42^{\prime \prime} \mathrm{W}, 40 \mathrm{~m}$ a.s.1.). One male adult with abdominal testes (forearm length of $34.70 \mathrm{~mm}$ and weight of $4.0 \mathrm{~g}$ ) was captured at 21:15 hours on 10/08/1998 in a mist net opened at a lake edge in the Guapiaçú Reserve, Guapiaçú, RJ (22 $22^{\circ} 21.2$ " $\mathrm{S}$ and $42^{\circ} 50^{\prime} 51.1^{\prime \prime} \mathrm{W}$, $240 \mathrm{~m}$ a.s.1.). One sub-adult female (forearm length of $35.05 \mathrm{~mm}$ and weight of $5.6 \mathrm{~g}$ ) was captured at 1 hour and 10 minutes on 03/03/2005 in a mist net opened on an artificial lake edge in the Ilha da Gipóia, Angra dos Reis, RJ (23 $3^{\circ} 02^{\prime} 48.9^{\prime \prime} \mathrm{S}$ and $44^{\circ} 21^{\prime}$ 42,4” W, $25 \mathrm{~m}$ a.s.1.).
Records from eastern Brazil, Bahia - One subadult female (forearm length of $34.90 \mathrm{~mm}$ and weight of $4.6 \mathrm{~g}$ ) was netted on 17/02/1998 exiting the Pedra Suspensa Cave, Pau-Brasil, Bahia (15 ${ }^{\circ} 23^{\prime} 34^{\prime \prime} \mathrm{S}$ and $39^{\circ} 44^{\prime} 26^{\prime \prime} \mathrm{W}$, c. $200 \mathrm{~m}$ a.s.l.) (Figure 1). This cave has a $150 \mathrm{~m}$ long, unique cavity that is inhabited by eight other bat species and has a large bat guano deposit. One adult male (forearm length of $39.00 \mathrm{~mm}$ and weight of $5.0 \mathrm{~g}$ on 04/05/1999) was netted immediately after sunset in a mist net placed close $(<2 \mathrm{~m})$ to a patch of Heliconidae plants located in a cacao (Theobroma cacao) plantation that is shaded by remnant native canopy trees in the Una municipality, southern Bahia (15 $10^{\prime} 53^{\prime \prime} \mathrm{S}$ and $30^{\circ} 02$ ' 51' W, c. $100 \mathrm{~m}$ a.s.1.).

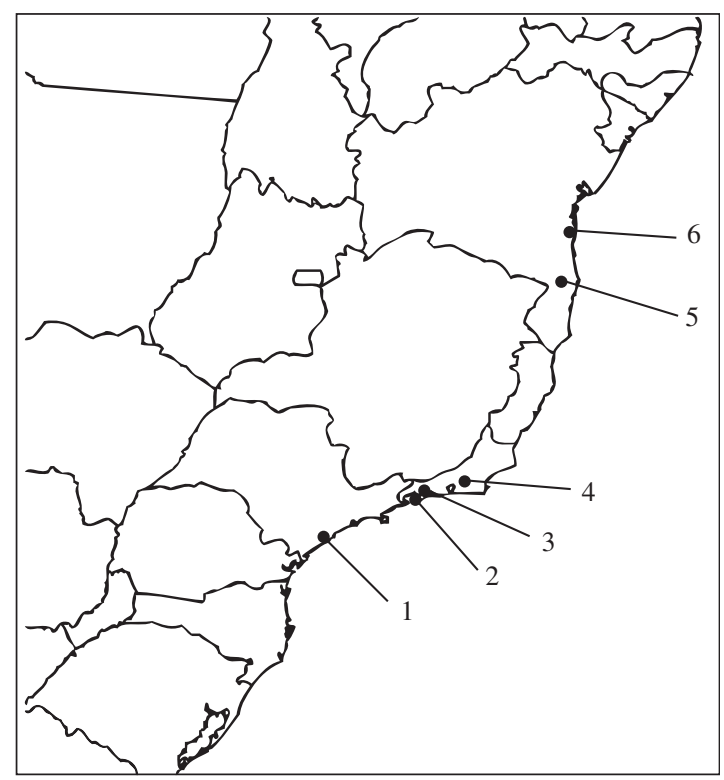

Figure 1. Records of Thyroptera tricolor juquiaensis in the Atlantic Forest. 1) Rio Iguape, Juquiá, São Paulo (Vieira, 1942); 2) Ilha da Gipóia, Angra dos Reis, Rio de Janeiro, (Vieira, 1955); 3) Reserva Rio das Pedras, Mangaratiba, Rio de Janeiro; 4) Reserva de Guapiaçú, Guapiaçú, Rio de Janeiro; 5) Gruta Pedra Suspensa, Pau-Brasil, Bahia; and 6) Una, Bahia. 
These records revealed that this species makes use of caves, in addition to the known Heliconidae plants, as day roosts. We also suggest the use of water bodies as foraging habitats, since four of the five captures were recorded over streams or near lakes and we confirm allnight activity for the species, with the capture of two bats in the latter half of the night and one less than 1.5 hours prior to sunrise.

Vouchers of the species were deposited in Universidade Estadual Santa Cruz, in the reference collection of Projeto Morcegos Urbanos (UFRRJ) and in the colletion Adriano Lúcio Peracchi (UFRRJ) and in the Adriano Peracchi Collection (UFRRJ).

Acknowledgments - We thank the Universidade Estadual de Santa Cruz and the Fazenda da Gipóia for the financial support for the fieldwork; the Guapiaçú and Rio das Pedras Reserves for permission for sampling. André Pol allowed the use of unpublished records at the Guapiaçú Reserve obtained during joint sampling between UFRRJ and RIOZOO. Renato Gregorin helped us with references and criticism and Adriano L. Peracchi with manuscript comments. Brenda Clifton improved the English. This work was accomplished under the license (Processes 1785/89-IBAMA and 4156/95-46 AC-SUPES/DF/ IBAMA to C.E.L. Esberrard). During the development of this study, C.E.L. Esbérard received a grant from CNPq (Process number 152910/2004-0).

\section{References}

FINDLEY, JS. and WILSON, DE. 1974. Observations on the neotropical disk-winged bat, Thyroptera tricolor Spix. Journal of Mammalogy, vol. 55, no. 3, p. 562-571.

GREGORIN, R., GONÇALVES, E., LIM, BK and ENGSTROM, MD., 2006, New species of disk-winged bat Thyroptera and range extension for $T$. discifera. Journal of Mammalogy, vol. 87, no. 2, p. 238-246.

VIEIRA, CO. da. 1942. Ensaio monográfico sobre os quirópteros do Brasil. Arquivos de Zoologia de São Paulo, vol. 3 , no. 8 , p. $422-471$.

-, 1955. Lista remissiva dos Mamíferos do Brasil. Arquivos de Zoologia do São Paulo, vol. 8, no. 11, p. 341-474.

VIZOTTO, LD. and TADDEI, VA. 1973. Chave para a determinação dos quirópteros brasileiros. Revista da Faculdade de Filosofia, Ciências e Letras (São José do Rio Preto), vol. 1, no. 1, p. 1-72.

VONHOF, MJ. and FENTON, MB. 2004. Roost availability and population size of Thyroptera tricolor, a leaf-roosting bat, in north-eastern Costa Rica. Journal of Tropical Ecology, vol. 20, no. 1, p. 291-305.

VONHOF, MJ., WHITEHEAD, H. and FENTON, MB. 2004. Analysis of Spix's disc-winged bat association patterns and roosting home ranges reveal a novel social structure among bats. Animal Behaviour, vol. 68, no. 3, p. 507-521.

WILSON, DE. and FINDLEY, JS. 1977. Thyroptera tricolor. Mammalian Species, vol. 71, p. 1-3. 